\title{
Pengaruh Penerimaan Teknologi Dalam Pembelajaran E-Learning Terhadap Peningkatan Minat Belajar Siswa (Studi Kasus Di Smk Pasundan Subang)
}

\author{
Ade Suparman \\ Fakultas Ilmu Administrasi, Universitas Subang \\ Email : adesuparmanjurna109@gmail.com
}

\begin{abstract}
Abstrak
Penelitian ini bertujuan untuk mengetahui pengaruh antar variabel dalam model TAM yang berkaitan dengan penggunaan pembelajaran e-learning di SMK Pasundan dengan mengambil sampel sebanyak 120 siswa SMK Pasundan dari berbagai kompetensi dan keahlian. Berdasarkan hasil analisis SEM, diperoleh hasil bahwa Availability Resources (ketersediaan sumber daya) berpengaruh signifikan terhadap Perceived Usefulness (persepsi kegunaan) dan Perceived Easy of Use (persepsi kemudahan). Perceived Usefulness (persepsi kemudahan) berpengaruh signifikan terhadap Perceived Easy of Use (persepsi kegunaan). Perceived Usefulness (persepsi kegunaan) dan Perceived Easy of Use (persepsi kemudahan) sama-sama berpengaruh terhadap Attitude Toward Use (sikap penggunaan), Perceived Usefulness (persepsi kegunaan) PU berpengaruh dan signifikan terhadap Behaviour Intention (minat penggunaan). Attitude Toward Use (sikap penggunaan) berpengaruh signifikan terhadap Behaviour Intention (minat penggunaan). Behaviour Intention (minat penggunaan), berpengaruh signifikan terhadap Actualy System Use (aktualisasi penggunaan). Perceived Usefulness (persepsi kemudahan). Perceived Easy of Use (persepsi kegunaan) dan Actualy System Use (aktualisasi penggunaan) berpengaruh signifikan terhadap Interest to Learn (minat belajar). Dengan demikian Pendekatan Teknologi dalam Model Pembelajaran E-Learning mempunyai berpengaruh positif dan signifikan terhadap peningkatan minat belajar siswa siswa di SMK Pasundan .
\end{abstract}

Kata kunci : model pendekatan teknologi, persepsi kegunaan, persepsi kemudahan, minat belajar.

\footnotetext{
Abstract

This research aims is to know the influences between variables in the model TAM with regard to the use of e-learning in learning CMS Pasundan with taking samples as many as 120 students of SMK Pasundan from different competence and expertise. Based on the results of SEM analysis, the results obtained that Availability Resources have a significant effect on Perceived Usefulness and Perceived Easy of Use. Perceived Usefulness has a significant effect
} 
on Perceived Easy of Use. Perceived Usefulness and Perceived Easy of Use both affect Attitude Toward Use. Perceived Usefulness (perceptions of use) influences and is significant on BI Behavior Intention Attitude Towards Use has a significant effect on BI Behavior Intention (interest in use. Behavior Intention (interest in use) has a significant effect on ASU's Actualy System Use,. Perceived Usefulness (PU), Perceived Easy of Use (perceptions of use) PEU and Actualy System Use (actualization of use) ASU has a significant effect on Interest to Learn. Thus the Technology Approach in the E-Learning Learning Model has a positive and significant effect on increasing the interest of learn for students in SMK Pasundan Subang.

Keyword : technology acceptance models, perceived usefulness, perceived easy of use, interest to learn.

\section{Pendahuluan}

Pendidikan adalah suatu usaha sadar dan terencana untuk mewujudkan suasana belajar dan proses pembelajaran yang aktif dan dapat mengembangkan potensi dirinya supaya memiliki kekuatan spiritual, emosional, pengendalian diri, kepribadian serta keterampilan yang diperlukan oleh masyarakat. Pembelajaran adalah proses interaksi antar peserta didik, antara peserta didik dan pendidik, dan antara peserta dan sumber belajar lainnya pada suatu lingkungan belajar yang berlangsung secara edukatif, agar peserta didik dapat membangun sikap, pengetahuan dan keterampilannya untuk mencapai tujuan yang telah ditetapkan. Selaras dengan itu pembelajaran merupakan suatu proses yang mengandung serangkaian kegiatan mulai dari perencanaan, pelaksanaan hingga penilaian untuk mencapai perubahan tingkah laku sebagai hasil pengalaman.

Proses belajar di sekolah selama ini selalu menempatkan siswa sebagai objek yang harus diisi beragam bahan-bahan ajar yang bertumpuk. Terjadinya komunikasi satu arah antara guru dan siswa dalam pembelajaran konvensional masih banyak dilakukan di dunia pendidikan di Indonesia. Sehingga secara tidak langsung kreativitas dan minat belajar siswa telah menurun karena hanya terpaku pada guru saja.

Banyak hal yang dapat mempengaruhi keberhasilan pembelajaran, salah satunya adalah minat belajar. Minat untuk belajar mengacu pada cara siswa berpikir tentang diri mereka sendiri sehubungan dengan kegiatan proses belajar (Sheldon, Turban, Brown, Barrick, \& Judge, 2012). Selain itu dengan adanya minat maka akan terlihat pencapaian prestasi selama belajar yang akan membawa siswa pada keinginan untuk terus belajar. Adanya suatu keberhasilan dalam belajar atau kepuasan dalam belajar seorang individu dapat berpengaruh kuat pada belajar berkelanjutan (Jose Luis Arquero, Carmen Fernández-Polvillo,Trevor Hassall and John Joyce, 2015).

Faktor yang mempengaruhi tersebut adalah intern dan ekstern, Faktor intern adalah faktor yang ada dalam diri peserta didik itu sendiri seperti motivasi, sedangkan faktor ekstern adalah faktor yang datang dari luar peserta didik, diantaranya adalah metode pembelajaran, lingkungan keluarga dan lingkungan 
Sekolah Slameto (2003:54) dalam jurnal (Khafid, 2004), Dalam faktor eksternal penumbuhan minat belajar salah satunya di dorong oleh kemudahan-kemudahan yang didapat dalam proses belajar, salah satunya adalah pendekatan teknologi. Dengan berkembangnya teknologi diharapkan adanya perubahan sikap pada siswa tersebut dalam menumbuhkan minat belajarnya.

Guru yang kompeten akan lebih mampu menggunakan bermacam-macam metode mengajar, media, dan model pembelajaran yang sesuai dengan tujuan dan kompetensi yang ingin dicapa. Salah satu kemampuan yang harus dimiliki guru adalah pemilihan model pembelajaran yang tepat, yang mampu merangsang minat siswa dalam proses belajar mengajar.

Dalam penelitian ini, peneliti mencoba menerapkan model pembelajaran kooperatif yang berbasis komputer, saat ini ketika kita menghadapi revolusi industri 4.0 semua sudah memasuki era digital. Mau tidak mau era digital ini sudh masuk ke dunia pendidikan dimana belajar tidak menuntut siswa harus selalu berada di dalam kelas, harus selalu mendengarkan guru,mereka dapat belajar dimanapun, dan membuka materi kapanpun dan mengakses mata pelajaran dengan baik,sehingga menuntut kemampuan guru dan siswa dalam menggunakan teknologi.

Selain dari model pembelajaran, proses belajar dan mengajar dewasa ini tidak terlepas dari peranan Media TIK (Teknologi Informasi dan Komunikasi). Pemanfaatan teknologi dalam proses pembelajaran mendorong terciptnya suatu pembelajaran yang melahirkan konsep baru dalam pembelajaran yang berbasis IT atau yang dikenal dengan E-Learning. Menurut Rosenberg (2000), pengembangan pendidikan menuju e-learning merupakan suatu alternatif dalam meningkatkan standar mutu pendidikan, dalam meningkatkan standart mutu pendidikan, karena e-learning merupakan satu penggunaan teknologi internet dalam penyampaian pembelajaran dengan jangkauan luas dan berlandaskan tiga kriteria yaitu : (1) elearning merupakan jaringan dengan kemampuan untuk memperbaharui, menyimpan, mendistribusi dan membagi materi ajar atau informasi, (2) pengiriman sampai ke pengguna terakhir melalui komputer dengan menggunakan teknologi internet yang standar, (3) memfokuskan pada pandangan yang paling luas tentang pembelajaran di balik paradigm pembelajaran tradisional.(Akhmad Faturrohman, 2011)

E-learning merupakan media pembelajaran yang memanfaatkan media elektronik sebagai alat bantu dalam proses kegiatan belajar mengajar untuk meningkatkan. E-learning dapat membantu guru dalam kegiatan belajar mengajar, karena E-learning dapat digunakan kapan saja meskipun jam pelajaran sudah habis, dan dapat digunakan tanpa harus bertatap muka antara guru dengan peserta didik. Schoology merupakan salah satu dari beberapa Learning Management System (LMS) yang memberikan fasilitas kepada guru dan peserta didik untuk saling berinteraksi, bertukar informasi secara online. Dengan adanya Schoology diharapkan siswa dapat 
mengunduh materi pelajaran, slide presentasi, video tutorial, game, mengerjakan quis, ujian, diskusi, dan pengumpulan tugas yang diberikan oleh pengajar. Schoology juga dapat digunakan melalui smartphone.

Dalam Era Globalisasi ini tak dapat dipungkiri lagi bahwa saat ini teknologi sudah sangat penting khususnya dalam dunia pendidikan tidak terkecuali sudah mulai memanfaatkan kecanggihan teknologi sebagai model pembelajaran (Widiyanto, Hikmawan, \& Riswanda, 2019). Diantara model pembelajaran tersebut adalah model pembelajaran berbasis web (e-learning). E-learning dapat didefinisikan sebagai "pelatihan atau prakarsa pendidikan yang menyediakan materi pembelajaran di repositori online, dimana interaksi dan komunikasi kursus dan penyampaian kursus adalah teknologi "dimediasi" (Johnson et al, 2008). Pembelajaran berbasis web ini atau inisiatif e-learning menyediakan materi pembelajaran dan komunikasi dalam konten secara elektronik melalui mediasi teknologi (Eddy, E.R. and Tannenbaum, 2003). Meskipun penelitian telah menemukan bahwa siswa dalam pembelajaran e-learning dapat belajar banyak melalui tatap muka (FTF) (Sitzmann, T. et.al, 2006), model pembelajaran e-learning masih ada kekurangan, yang perlu ditangani (Welsh, et al). Melalui pendekatan teknologi kemudahan (perceived ease) dan Kegunaan (perceived usefulnees) dalam pembelajaran e-learning akan sangat mempengaruhi adanya kepuasan siswa dalam belajar sehingga timbul minat yang responsive dalam diri siswa untuk belajar.

Dalam penggunaan model pembelajaran e-learning ini peneliti menggunakan Model Penerimaan Teknologi atau dikenal dengan teori TAM, dimana peneliti ingin mengukur niat penggunaan (Behavioral Intention), yang dipengaruhi oleh kemudahan penggunaan (Ease of use) dan kemanfaatan (Usefulnees) teknologi. David et.all,(1989) dalam dalam Fathul Wahid, 2007, model ini secara lebih jelas menggambarkan bahwa penerimaan penggunaan teknologi dipengaruhi oleh kemanfaatan dan kemudahan penggunaan dengan availability of resaources sebagai variabel eksternal sebagai mediator yang mempengaruhi kemudahan penggunaan (Ease of use) dan kemanfaatan (Usefulnees) teknologi, dan Kehadiran Internet di perguruan tinggi bertujuan untuk menumbuhkan minat belajar siswa jika digunakan dengan tepat agar prestasi siswa dapat meningkat. Berdasarkan hal tersebut diperlukan juga pengujian apakah teknologi dapat mempengaruhi minat belajar siswa.

\section{Kerangka Teori}

\section{Hakikat Minat Belajar Dan Indikator Minat Belajar Siswa}

Sebelum kita menelaah minat belajar maka kita harus mengetahui terlebih dahulu pengertian minat dan belajar. Kata minat secara etimologi berasal dari bahasa inggris "interest" yang berarti kesukaan, perhatian (kecenderungan hati pada sesuatu), keinginan. Sedangkan belajar adalah suatu proses perubahan diri 
dari tidak tahu menjadi tahu, dari tidak mengerti menjadi mengerti. Jadi dalam proses belajar siswa harus mempunyai minat atau kesukaan untuk mengikuti kegiatan belajar yang berlangsung, karena dengan adanya minat akan mendorong siswa untuk menunjukan perhatian, aktivitasnya dan partisipasinya dalam mengikuti belajar yang berlangsung.

Menurut Dewey (1913), menyarankan untuk mencari tahu apa yang menarik bagi siswa merupakan bagian penting dari sekolah, di sisi lain, "membuat hal-hal yang menarik" adalah buatan dan sering tidak berhasil. Dalam konsep Teori Motivasi menyatakan bahwa minat adalah istilah yang menunjukkan karakteristik pribadi atau keadaan afektif dan yang telah diselidiki secara menyeluruh oleh psikologi motivasi modern. khususnya, minat tidak lebih dari istilah awam untuk motivasi intrinsik.(Ulrich Schiefele, 1991,hlm. 301).

Menurut pendapat Slameto, (2015. hlm. 180), Minat adalah suatu rasa lebih suka dan lebih keterikatan pada suatu hal atau aktivitas, tanpa ada yang menyuruh. Minat pada dasarnya adalah penerimaan akan suatu hubungan antara diri sendiri dengan sesuatu diluar diri. Semakin kuat atau dekat hubungan, semakin besar minat. Minat pada dasarnya adalah penerimaan akan suatu hubungan antara diri sendiri dengan sesuatu di luar diri. Minat merupakan ketertarikan atau perasaan senang terhadap sesuatu. Minat mempunyai pengaruh yang besar terhadap belajar Minat terhadap pelajaran dapat merangsang siswa untuk menambah kegiatan belajar. Hal itu sesuai dengan pendapat Slameto (2015, hlm. 57) yang menyatakan bahwa "minat adalah kecenderungan yang tetap untuk memperhatikan dan mengenang beberapa kegiatan".

Menurut Jugiyanto, (2007) dalam Minat merupakan suatu keinginan seseorang untuk melakukan suatu perilaku tertentu. Dapat dikatakan bahwa seseorang akan melakukan suatu hal tertentu apabila memiliki kemauan dari dalam diri untuk melakukannya. Sedangkan menurut Djamarah (2017) minat adalah suatu penerimaan akan suatu hubungan antara diri sendiri dengan sesuatu di luar diri. Sementara menurut Slameto (2015) menyatakan bahwa minat adalah suatu rasa lebih suka (senang) dan rasa ketertarikan pada suatu hal atau aktivitas.

Pada umumnya minat seseorang terhadap sesuatu akan diekspresikan melalui kegiatan atau aktivitas yang akan berkaitan dengan minatnya. Sehingga untuk mengetahui indikator minat dapat dilihat dengan cara menganalisa kegiatankegiatan yang dilakukan oleh individu pada objek yang disenanginya, karena minat merupakan motif yang dipelajari sehingga mendorong individu untuk aktif dalam kegiatan tertentu. Dengan demikian untuk menganalisa minat belajar dapat digunakan beberapa indikator minat sebagai berikut :

Selain itu menurut Djamarah, (2017 : 132) mengungkapkan bahwa minat dapat diekpresikan anak didik melalui :

a. Pernyataan lebih menyukai sesuatu daripada yang lainnya

b. Partisipasi dalam aktif dalam suatu kegiatan 
c. Memberikan perhatian yang lebih besar yang lebih besar terhadap sesuatu yang diminatinya tanpa menghiraukan yang lain (fokus)

Menurut Safari (dalam Herlina, 2010 : 20) , bahwa untuk mengetahui berapa besar minat belajar siswa, dapat diukur melalui:

a. Kesukaan, pada umumnya individu yang suka pada sesuatu disebabkan karena adanya minat. biasanya apa yang paling disukai mudah sekali untuk diingat. Sama halnya dengan siswa yang berminat pada suatu mata pelajaran tertentu akan menyukai pelajaran itu.

b. Ketertarikan, seringkali dijumpai beberapa siswa yang merespon dan memberikan reaksi terhadap apa yang disampaikan guru pada saat proses belajar mengajar di kelas.

c. Perhatian, semua siswa yang mempunyai minat terhadap pelajaran tertentu akan cenderung memberikan perhatian yang besar terhadap pelajaran itu.

d. Keterlibatan yakni keterlibatan, keuletan, dan kerja keras yang tampak melalui diri siswa menunjukkan bahwa siswa tersebut ada keterlibatannya dalam belajar di mana siswa selalu belajar lebih giat, berusaha menemukan hal-hal yang baru yang berkaitan dengan pelajaran yang diberikan guru di sekolah.

Dari beberapa pendapat tersebut tersebut dapat disimpulkan bahwa minat belajar siswa dapat dilihat dari bagaimana siswa tersebut dalam melakukan aktivitas yang mereka ikuti dan sangat di senangi, ketertarikan mereka untuk ikut terlibat berpartisipasi aktif dalam proses pembelajaran serta perhatian yang mereka berikan. Dengan demikian, indikator minat yang digunakan sebagai acuan penelitaian ini adalah indikator-indikator minat sebagaimana diuraikan sebelumnya yakni meliputi kesukaan, ketertarikan, perhatian dan keterlibatan mereka dalam kegiatan yang besar manfaatnya, dan keinginan untuk menggunakannya,

\section{Media Pembelajaran Berbasis Internet (E-Learning)}

Kemajuan ICT, proses ini dimungkinkan dengan menyediakan sarana pembelajaran online melalui internet dan media elektronik. Konsep pembelajaran berbasis ICT seperti ini lebih dikenal dengan e-learning. E-learning atau electronic learning kini semakin merupakan salah satu cara untuk mengatasi masalah pendidikan, baik di Negara-negara maju maupun dinegara yang sedang berkembang. Banyak orang yang menggunakan istilah berbeda untuk e-learning, namun pada prinsipnya e-learning adalah pembelajaran yang menggunakan jasa elektronika sebagai alat bantunya.

Dalam pelaksaannya e-learning menggunakan jasa audio, video atau perangkat komuputer atau kombinasi dari ketiganya. Harley menyatakan bahwa e-learning merupakan suatu jenis belajar mengajar yang memungkinkan tersampaikannya bahan ajar ke siswa dengan menggunakan media internet, intranet, atau media jaringan komputer lain.

Dalam pemanfaatannya sebagai media pembelajaran jarak jauh, Implementasi E-Learning dibagi menjadi 3 bentuk diantanya : 


\section{Suplemen/Tambahan}

Bentuk implemetasi yang berupa tambahan dilakukan apabila peserta e-learning mempunyai kebebasan memilih, untuk memanfaatkan materi pembelajaran elektronik atau tidak. Dalam hal ini, tidak ada kewajiban atau keharusan bagi peserta e-learning untuk mengakses materi pembelajaran elektronik. Sekalipun sifatnya opsional, peserta didik yang memanfaatkannya tentu memiliki tambahan pengetahuan atau wawasan.

2. Komplemen/Pelengkap

Bentuk implementasi yang berupa pelengkap apabila materi e-learning diprogramkan untuk melengkapi materi pembelajaran yang diterima peserta elearning di dalam kelas pembelajaran. Sebagai komplemen/tambahan yang artinya materi e-learning digunakan untuk menjadi materi enrichment/pengayaan bagi peserta e-learning di dalam mengikuti kegiatan pembelajaran konvensional. Sebagai enrichment, apabila peserta e-learning dapat dengan cepat menguasai/ memahami materi pembelajaran yang disampaikan pengajar secara tatap muka maka peserta e-learning diberikan kesempatan untuk mengakses materi e-learning yang memang secara khusus dikembangkan untuk mereka.

3. Substitusi / Pengganti

Dalam bentuk implemetasi sebagai pengganti/menjalankan e-learning secara penuh sebagai pengganti kelas konvensional adalah agar peserta e-learning dapat secara fleksibel mengelola kegiatan pembelajaran sesuai dengan waktu dan aktivitas lain sehari-hari.

\section{Technology Acceptance Model (TAM)}

Model penerimaan teknologi (TAM) seperti yang dikutip oleh Yousafzai, Foxall, \& Pallister (2007), awalnya diformulasikan oleh Davis (1986) adalah satu model yang paling banyak diuji penerimaan teknologi. TAM mengadaptasi Ajzen dan Fishbein (1980) teori tindakan beralasan (TRA) untuk menjelaskan hubungan sebab-akibat antara keyakinan internal pengguna (kegunaan dan kemudahan penggunaan), sikap, niat, dan perilaku penggunaan komputer (Davis et al., 1989)

Technology Acceptance Model (TAM) merupakan suatu model penerimaan sistem teknologi informasi yang akan digunakan oleh pemakai. Model penerimaan teknologi (TAM) dikembangkan oleh (Davis,et al, 1989) berdasarkan model TRA.(Subakdo Eko Yulianto, 2011)

Model TAM sebenarnya diadopsi dari model TRA yang dirancang untuk menjelaskan perilaku manusia dan terdiri dari dua faktor yang mempengaruhi intensi perilaku, sikap terhadap perilaku dan norma subyektif. Teori ini membuat model perilaku seseorang sebagai suatu fungsi dari tujuan perilaku, reaksi dan persepsi pengguna. Teknologi Informasi (TI) akan mempengaruhi sikapnya dalam penerimaan terhadap teknologi tersebut. Salah satu faktor yang dapat mempengaruhinya adalah persepsi pengguna terhadap kemanfaatan dan kemudahan penggunaan TI sebagai suatu tindakan yang beralasan dalam konteks 
pengguna teknologi, sehingga alasan seseorang dalam melihat manfaat dan kemudahan penggunaan TI menjadikan tindakan/perilaku orang tersebut sebagai tolok ukur dalam penerimaan sebuah teknologi. Model TAM yang dikembangkan dari teori psikologis, menjelaskan perilaku pengguna komputer yaitu berlandaskan pada kepercayaan (belief), sikap (attitude), keinginan (intention) dan hubungan perilaku pengguna (user behaviour relationship). Tujuan model ini untuk menjelaskan faktor-faktor utama dari perilaku pengguna terhadap penerimaan pengguna teknologi.

Model TAM yang dikembangkan oleh Davis (1989) juga mendapat perluasan dari para peneliti seperti Iqbaria (1994), dan (Chin. W. W.and Todd, 1995). Seperti pada gambar berikut:

\section{Gambar 1 Model Penerimaan Teknologi Davis et al (1989)}

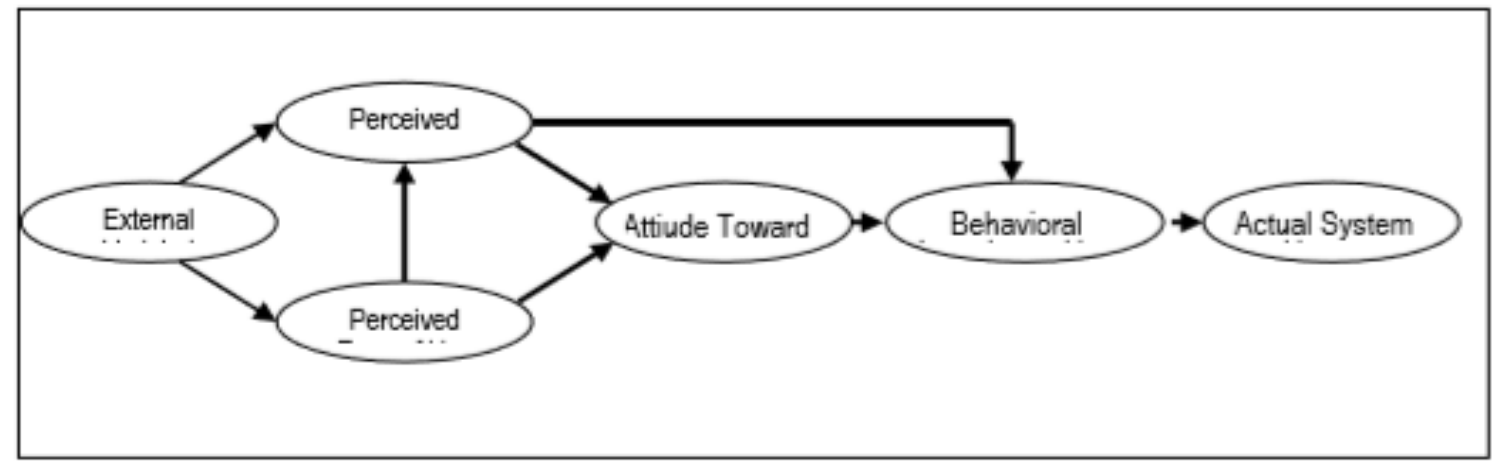

(Sumber: Budi Santoso, Rauniar, Rawski, Yang, E Johnson (2013))

Gambar di atas menjelaskan hubungan antar konstruk yang terdapat dalam TAM (Davis, et al, 1989) dimana konstruksi external variable dinilai akan berpengaruh terhadap konstruksi Perceived Usefulness dan Perceived Ease Of Use. Konstruksi Perceived Ease of use dianggap akan berpengaruh terhadap konstruksi Perceived Usefulness. Dilin pihak kedua konstruksi (Perceived Usefulness dan Perceived Ease Of Use) sama-sama memiliki pengaruh terhadap konstruksi attitude toward using. Konstruksi Perceived Usefulness akan berpengaruh terhadap behavioral intention to use selain itu behavioral intention to use juga akan dipengaruhi oleh konstruksi attitude toward using dan sekaligus akan mempengaruhi konstruksi actual usage.

\section{Metode Penelitian}

\section{Desain Penelitian}

Penelitian ini menggunakan: Desain Non-ekperimental, tujuan ialah bersifat eksplorasi dan deskriptif;. Yang termasuk dalam kategori pertama desain atau rancangan penelitian deskriptif, Desain Penelitian Deskriptif dilakukan dengan tujuan untuk mendiskripsikan atau menggambarkan fakta-fakta mengenai populasi secara sistematis, dan akurat tentang pendekatan teknologi terhadap model pembelajaran e-learning di SMK Pasundan. Studi kasus merupakan rancangan 
penelitian yang mencakup pengkajian satu unit penelitian secara intensif, misalnya satu pasien, keluarga, kelompok, komunitas, atau institusi (Nursalam, 2003 : 83). Karakteristik studi kasus adalah subjek yang diteliti sedikit tetapi aspek-aspek yang diteliti banyak.

\section{Populasi Dan Sampel}

Populasi yang diambil dalam penelitian ini adalah siswa SMK Pasundan Subang. Dari keseluruhan jumlah siswa yang menerima model pembelajaran $e$ learning hanya ada 4 kompetensi keahlian, di kelas X dan XI dan di mata pelajaran tertentu, peneliti membatasi populasi karena keterbatasan waktu dan guru yang menggunakan model pembelajaran e-learning berbasis schoology masih terbatas. Berikut jumlah siswa yang menjadi jumlah populasi dapat dilihat pada tabel 1:

\section{Tabel 1}

Jumlah Responden yang Mendapatkan Pembelajaran e-Learning

\begin{tabular}{|c|l|c|c|c|}
\hline No & \multicolumn{1}{|c|}{ Kompetensi Keahlian } & Kelas X & Kelas XI & Total \\
\hline 1 & Rekayasa Perangkat Lunak & 35 & - & 35 \\
\hline 2 & Teknik Komputer Jaringan & 36 & 21 & 57 \\
\hline 3 & $\begin{array}{l}\text { Otomatisasi dan Tata Kelola } \\
\text { Perkantoran }\end{array}$ & 47 & - & 47 \\
\hline 4 & Akuntasi & 33 & - & 33 \\
\hline Jumlah & 152 & 21 & 172 \\
\hline
\end{tabular}

Sumber : Dapodik SMK Pasundan

Dari keseluruhan populasi ini, peneliti mendapatkan dilapangan bahwa kelas XI sedang melaksanakan PKL dari bulan Oktober-Desember, dan hanya ada kelas XI TKJ sehingga peneliti hanya mendapatkan responden dengan jumlah 172 siswa, kemudian inilah yang akan menjadi perhitungan sampel penelitian

Hasil dari perhitungan slovin responden yang diambil sampel yang menjadi responden dalam penelitian ini dilakukan dengan mencari sampel jumlah kelas yang mendekati jumlah sampel, jadi sampel yang diambil adalah sebanyak 120 siswa, hal ini dilakukan untuk mempermudah dalam pengolahan data dan untuk hasil pengujian yang lebih baik. Pembagian jumlah sampel yang diambil dari tiaptiap kompetensi keahlian dapat dilihat dari tabel 2:

Tabel 2

Pengambilan Sampel Penelitian

\begin{tabular}{|l|l|c|c|c|}
\hline No & Kompetensi Keahlian & Jumlah Siswa & Rumus & Jumlah sampel \\
\hline 1 & $\begin{array}{l}\text { Rekayasa Perangkat } \\
\text { Lunak }\end{array}$ & 35 & $\mathrm{i}=\frac{35}{171} \cdot 120$ & 24 \\
\hline
\end{tabular}




\begin{tabular}{|l|l|c|c|c|}
\hline 2 & $\begin{array}{l}\text { Teknik Komputer } \\
\text { Jaringan }\end{array}$ & 57 & $\mathrm{i}=\frac{57}{171} \cdot 120$ & 40 \\
\hline 3 & $\begin{array}{l}\text { Otomatisasi dan Tata } \\
\text { Kelola Perkantoran }\end{array}$ & 47 & $\mathrm{i}=\frac{47}{171} \cdot 120$ & 33 \\
\hline 4 & Akuntasi & 33 & $\mathrm{i}=\frac{33}{171} \cdot 120$ & 23 \\
\hline \multicolumn{2}{|c|}{ Total } & 172 & & 120 \\
\hline
\end{tabular}

\section{Uji Instrumen Validitas dan Reliabilitas Instrumen Penelitian}

Dalam penelitian ini sebelum instrumen penelitian digunakan, dengan menggunakan uji validitas dan reliabilitas. Berikut ini adalah hasil uji validitas dan reliabilitas instrumen penelitian yang akan digunakan dalam penelitian ini seperti terlihat pada tabel 3:

Tabel 3

Hasil Uji Validitas dan Reliabilitas Instrumen

\begin{tabular}{|c|c|c|c|c|c|c|}
\hline Variebel & Indikator & $\begin{array}{c}\mathbf{R} \\
\text { Hitung }\end{array}$ & $\begin{array}{c}\mathbf{R} \\
\text { Tabel }\end{array}$ & Validitas & $\begin{array}{c}\text { Crombachs } \\
\text { Alpha }\end{array}$ & Reliabilitas \\
\hline \multirow{5}{*}{$\begin{array}{c}\text { Availability } \\
\text { Resources }\end{array}$} & ARS1 & 0,511 & 0,361 & Valid & \multirow{5}{*}{0,810} & \multirow{5}{*}{ reliabel } \\
\hline & ARS2 & 0,740 & 0,362 & Valid & & \\
\hline & ARS3 & 0,912 & 0,363 & Valid & & \\
\hline & ARS4 & 0,838 & 0,364 & Valid & & \\
\hline & ARS5 & 0,841 & 0,361 & Valid & & \\
\hline \multirow{5}{*}{$\begin{array}{l}\text { Perceived } \\
\text { Usefulness }\end{array}$} & PU1 & 0,483 & 0,361 & Valid & \multirow{5}{*}{0,814} & \multirow{5}{*}{ reliabel } \\
\hline & PU2 & 0,899 & 0,361 & Valid & & \\
\hline & PU3 & 0,914 & 0,361 & Valid & & \\
\hline & PU4 & 0,898 & 0,361 & Valid & & \\
\hline & PU5 & 0,622 & 0,361 & Valid & & \\
\hline \multirow{4}{*}{$\begin{array}{l}\text { Perceived } \\
\text { Easy to Use }\end{array}$} & PEU1 & 0,961 & 0,361 & Valid & \multirow{4}{*}{0,908} & \multirow{4}{*}{ reliabel } \\
\hline & PEU2 & 0,873 & 0,361 & Valid & & \\
\hline & PEU3 & 0,918 & 0,361 & Valid & & \\
\hline & PEU4 & 0,805 & 0,361 & Valid & & \\
\hline \multirow{4}{*}{$\begin{array}{c}\text { Attitude } \\
\text { Toward } \\
\text { Using }\end{array}$} & ATU1 & 0,922 & 0,361 & Valid & \multirow{4}{*}{0,936} & \multirow{4}{*}{ reliabel } \\
\hline & ATU2 & 0,928 & 0,361 & Valid & & \\
\hline & ATU3 & 0,905 & 0,361 & Valid & & \\
\hline & ATU4 & 0,918 & 0,361 & Valid & & \\
\hline \multirow{4}{*}{$\begin{array}{l}\text { Behaviour } \\
\text { Intention }\end{array}$} & BI1 & 0,955 & 0,361 & Valid & \multirow{4}{*}{0,951} & \multirow{4}{*}{ reliabel } \\
\hline & $\mathrm{BI} 2$ & 0,951 & 0,361 & Valid & & \\
\hline & BI3 & 0,935 & 0,361 & Valid & & \\
\hline & BI4 & 0,904 & 0,361 & Valid & & \\
\hline \multirow{4}{*}{$\begin{array}{c}\text { Actual } \\
\text { System Use }\end{array}$} & ASU1 & 0,929 & 0,361 & Valid & \multirow{4}{*}{0,899} & \multirow{4}{*}{ reliabel } \\
\hline & ASU2 & 0,906 & 0,361 & Valid & & \\
\hline & ASU3 & 0,930 & 0,361 & Valid & & \\
\hline & ASU4 & 0,738 & 0,361 & Valid & & \\
\hline \multirow{5}{*}{$\begin{array}{c}\text { Interest of } \\
\text { learn }\end{array}$} & IL1 & 0,883 & 0,361 & Valid & \multirow{5}{*}{0,908} & \multirow{5}{*}{ reliabel } \\
\hline & IL2 & 0,436 & 0,361 & Valid & & \\
\hline & IL3 & 0,928 & 0,361 & Valid & & \\
\hline & IL4 & 0,911 & 0,361 & Valid & & \\
\hline & IL5 & 0,905 & 0,361 & Valid & & \\
\hline
\end{tabular}




\begin{tabular}{|c|c|c|c|c|c|c|}
\hline Variebel & Indikator & $\begin{array}{c}\mathbf{R} \\
\text { Hitung }\end{array}$ & $\begin{array}{c}\mathbf{R} \\
\text { Tabel }\end{array}$ & Validitas & $\begin{array}{c}\text { Crombachs } \\
\text { Alpha }\end{array}$ & Reliabilitas \\
\hline \multirow{7}{*}{} & IL6 & 0,686 & 0,361 & Valid & & \\
\cline { 2 - 5 } & IL7 & 0,713 & 0,361 & Valid & & \\
\cline { 2 - 5 } & IL8 & 0,863 & 0,361 & Valid & & \\
\hline
\end{tabular}

Sumber : Hasil Olahan SPSS

Berdasarkan hasil uji validitas pada Tabel 3 tersebut, seluruh item pertanyaan pada masing-masing variabel penelitian memiliki nilai $r$ hitung di atas nilai $R$ Tabel $(0,361)$, sehingga seluruh item pertanyaan dalam instrumen penelitian dinyatakan valid dan dapat digunakan sebagai instrumen penelitian. Selanjutnya, berdasarkan hasil uji reliabilitas di atas, seluruh instrumen memiliki nilai crombachs alpha $>0,6$ yang berarti seluruh instrumen telah reliabel dan dapat digunakan.

\section{Analisis Data}

Pada penelitian ini digunakan perhitungan dengan menggunakan SEM, Menurut Sarjono (2014), dalam menggambarkan hubungan antar variabel terdapat dua pemodelan dalam SEM, model tersebut adalah :

1. Model Struktural (Structural Model)

Model struktural menggambarkan hubungan yang terjadi antara variabel-variabel laten. Menurut Wijanto(2007), hubungan-hubungan ini umumnya linear, meskipun perluasan SEM memungkinkan untuk mengikut sertakan hubungan non-linear.

2. Model Pengukuran (Measurement Model)

Model pengukuran adalah model yang menggambarkan hubungan yang terjadi antara variabel laten dengan indikator-indikatornya (variabel manifes).

\section{Hasil Dan Diskusi}

\section{Uji Normalitas}

Uji Normalitas dalam analisis SEM dimaksudkan untuk mengetahui normal tidaknya distribusi penelitian masing-masing variabel. Evaluasi normalitas dilakukan dengan menggunakan kriteria critical ration skewness value, data dikatakan berdistribusi normal jika nilai critical ratio skewness value di bawah harga mutlak 2,58 (Ghozali; 2016), sedangkan dalam Ferdinand (2006) nilai c.r multivariat di bawah 8 masih dapat diterima dan analisis masih dapat dilanjutkan asalkan seluruh indikator telah memiliki nilai c.r kurtosis $<$ dalam rentan $-2,58<\mathrm{z}<2,58$. Tabel 4 merupakan hasil uji normalitas data pada model.

Tabel 4

Hasil Uji Normalitas Assessment of normality (Group number 1)

\begin{tabular}{|l|llllll|}
\hline Variable & $\min$ & $\max$ & Skew & c.r. & kurtosis & c.r. \\
\hline
\end{tabular}




\begin{tabular}{|c|c|c|c|c|c|c|}
\hline Variable & $\min$ & $\max$ & Skew & c.r. & kurtosis & c.r. \\
\hline IL6 & 1.000 & 5.000 & -.361 & -1.615 & -1.029 & -2.301 \\
\hline IL7 & 1.000 & 5.000 & -.303 & -1.354 & -.924 & -2.066 \\
\hline IL8 & 1.000 & 5.000 & -.358 & -1.602 & -.977 & -2.185 \\
\hline IL5 & 1.000 & 5.000 & -.304 & -1.359 & -.862 & -1.928 \\
\hline IL4 & 1.000 & 5.000 & -.314 & -1.405 & -1.037 & -2.320 \\
\hline IL3 & 1.000 & 5.000 & -.233 & -1.040 & -.952 & -2.129 \\
\hline IL1 & 1.000 & 5.000 & -.376 & -1.683 & -.701 & -1.568 \\
\hline ASU3 & 1.000 & 5.000 & -.404 & -1.806 & -.282 & -.631 \\
\hline ASU2 & 1.000 & 5.000 & -.184 & -.824 & -.563 & -1.259 \\
\hline ASU1 & 1.000 & 5.000 & -.187 & -.837 & -.723 & -1.616 \\
\hline ASU4 & 1.000 & 5.000 & -.332 & -1.483 & -.748 & -1.672 \\
\hline BI4 & 1.000 & 5.000 & -.488 & -2.182 & -.481 & -1.075 \\
\hline BI3 & 1.000 & 5.000 & -.293 & -1.312 & -.723 & -1.616 \\
\hline BI2 & 1.000 & 5.000 & -.097 & -.436 & -.846 & -1.893 \\
\hline BI1 & 1.000 & 5.000 & -.323 & -1.443 & -.582 & -1.301 \\
\hline ATU1 & 1.000 & 5.000 & -.438 & -1.958 & -.395 & -.882 \\
\hline ATU2 & 1.000 & 5.000 & -.460 & -2.056 & -.492 & -1.101 \\
\hline ATU3 & 1.000 & 5.000 & -.210 & -.940 & -.888 & -1.985 \\
\hline ATU4 & 1.000 & 5.000 & -.229 & -1.022 & -.892 & -1.996 \\
\hline PU2 & 1.000 & 5.000 & -.327 & -1.463 & -.881 & -1.971 \\
\hline PEU1 & 1.000 & 5.000 & -.259 & -1.160 & -.825 & -1.845 \\
\hline PEU2 & 1.000 & 5.000 & -.406 & -1.817 & -.714 & -1.597 \\
\hline PEU3 & 1.000 & 5.000 & -.341 & -1.527 & -.954 & -2.134 \\
\hline PEU4 & 1.000 & 5.000 & -.216 & -.965 & -1.043 & -2.332 \\
\hline PU4 & 1.000 & 5.000 & -.477 & -2.132 & -.780 & -1.745 \\
\hline PU3 & 1.000 & 5.000 & -.559 & -2.502 & -.786 & -1.758 \\
\hline PU5 & 1.000 & 5.000 & -.279 & -1.248 & -1.136 & -2.540 \\
\hline PU1 & 1.000 & 5.000 & -.505 & -2.259 & -.681 & -1.524 \\
\hline ARS3 & 1.000 & 5.000 & -.204 & -.914 & -.290 & -.648 \\
\hline ARS4 & 1.000 & 5.000 & -.346 & -1.549 & -.302 & -.676 \\
\hline ARS5 & 1.000 & 5.000 & -.358 & -1.602 & -.428 & -.958 \\
\hline Multivariate & & & & & 16.801 & 2.034 \\
\hline
\end{tabular}

Sumber : Hasil Olahan AMOS

Hasil uji normalitas menunjukkan bahwa data penelitian telah berdistribusi normal karena nilai c.r skewness dan kurtosis univariat seluruh indikator telah berada dalam interval $-2,58<z<2,58$ begitu juga dengan nilai c.r multivariat sebesar 0,558 menunjukkan bahwa cr multivariat telah berada di dalam interval $-2,58<\mathrm{z}<$ 
2,58, hal ini menunjukkan bahwa data yang akan dianalisis telah beridistribusi normal baik secara univariat maupun multivariat.

\section{Uji Multikolinearitas}

Uji Multikolinearitas dilakukan dengan melihat nilai korelasi antar variabel eksogen. Model dinyatakan terbebas dari multikolinearitas jika nilai korelasi antar variabel $<0,9$. Hasil analisis pada tabel 5 menunjukkan tidak adanya multikolinearitas dalam model karena tidak ada koefisien korelasi antar variabel yang melebihi 0,9.

Tabel 5

Hasil Uji Multikolinearitas Correlations: (Group number 1 - Default model)

\begin{tabular}{|c|c|c|c|}
\hline & & & Estimate \\
\hline ARS & $<-->$ & PEU & .333 \\
\hline ARS & $<-->$ & PU & .625 \\
\hline PU & $<-->$ & ATU & .483 \\
\hline PU & $<-->$ & PEU & .404 \\
\hline ARS & $<-->$ & ATU & .425 \\
\hline ATU & $<-->$ & BI & .407 \\
\hline PU & $<-->$ & BI & .391 \\
\hline PEU & $<-->$ & BI & .349 \\
\hline ARS & $<-->$ & BI & .465 \\
\hline PU & $<-->$ & ASU & .114 \\
\hline BI & $<-->$ & ASU & .343 \\
\hline ATU & $<-->$ & ASU & .317 \\
\hline PEU & $<-->$ & ASU & .169 \\
\hline ARS & $<-->$ & ASU & .148 \\
\hline ASU & $<-->$ & IL & .311 \\
\hline BI & $<-->$ & IL & .365 \\
\hline ATU & $<-->$ & IL & .278 \\
\hline PEU & $<-->$ & IL & .525 \\
\hline
\end{tabular}




\begin{tabular}{|lcc|c|}
\hline & & & Estimate \\
\hline ARS & $<->$ & IL & .229 \\
PU & $<->$ & IL & .446 \\
PEU & $<->$ & ATU & .515 \\
\hline
\end{tabular}

Sumber : Hasil Olahan AMOS

\section{Pengujian Model Struktural}

Tahap-tahap dalam pengujian model struktural meliputi tahap pembentukan model struktural, uji kelayakan model struktural dan uji signifikansi pengaruh variabel eksogen terhadap variabel endogen.

\section{Spesifikasi Model Struktural}

Dengan mengacu pada hipotesis dan kerangkan model yang dibangun dalam penelitian ini dihasilkan pengujian model pengukuran yang menunjukkan bahwa indikator ARS1, ARS2 dan IL2 tidak valid dalam mengukur konstruknya, maka spesifikasi model analisis SEM yang dibangun hanya akan memuat 31 indikator adapun spesifikasi model nya seperti terlihat pada gambar 2 :

\section{Gambar 2 Spesifikasi Model SEM}

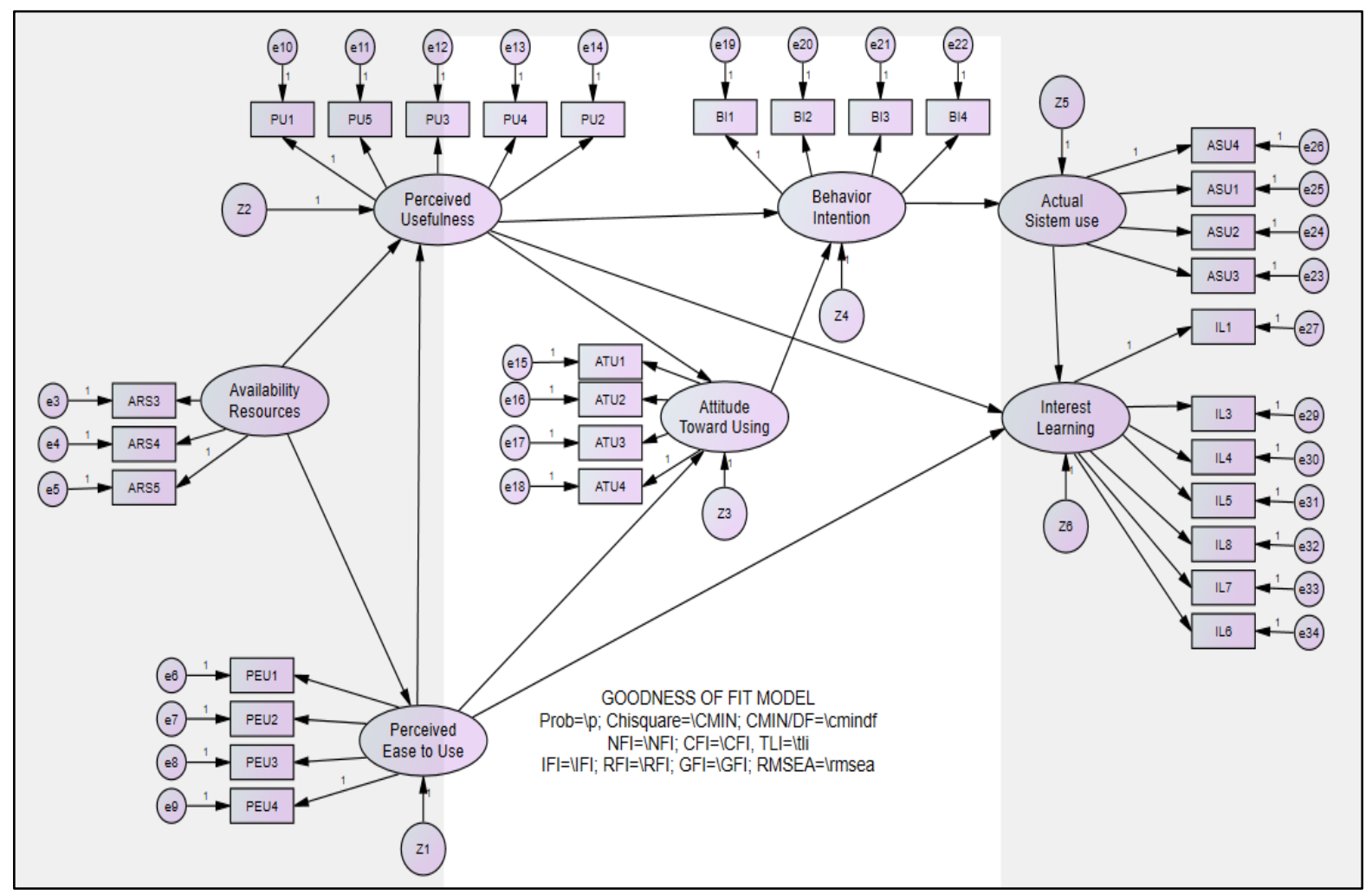




\section{Uji Kelayakan Model Struktural}

Uji kelayakan model struktural dalam analisis SEM dilakukan dengan melihat beberapa kriteria Goodness of fit model seperti nilai Chi Square, probabilitas, df, GFI, AGFI, TLI, CFI RMSEA dan RMR. Dalam penelitian ini, terpenuhinya Goodness of fit model akan difokuskan pada indikator goodness of fit model yang berupa nilai probabilitas dan Chi Square model. Nilai probabilitas dan Chi square model yang tidak signifikan (probabilitas > 0,05 dan Chi Square < Chi Square (0,05,df model)) menunjukkan bahwa model SEM yang diestimasi dengan data yang dianalisis memiliki matriks kovarian yang sama dengan matriks kovarian populasi sehingga dipastikan dapat memberikan gambaran kondisi populasi yang sebenarnya seperti terlihat pada gambar 4 :

\section{Gambar 3 Hasil Modifikasi Model Struktural}

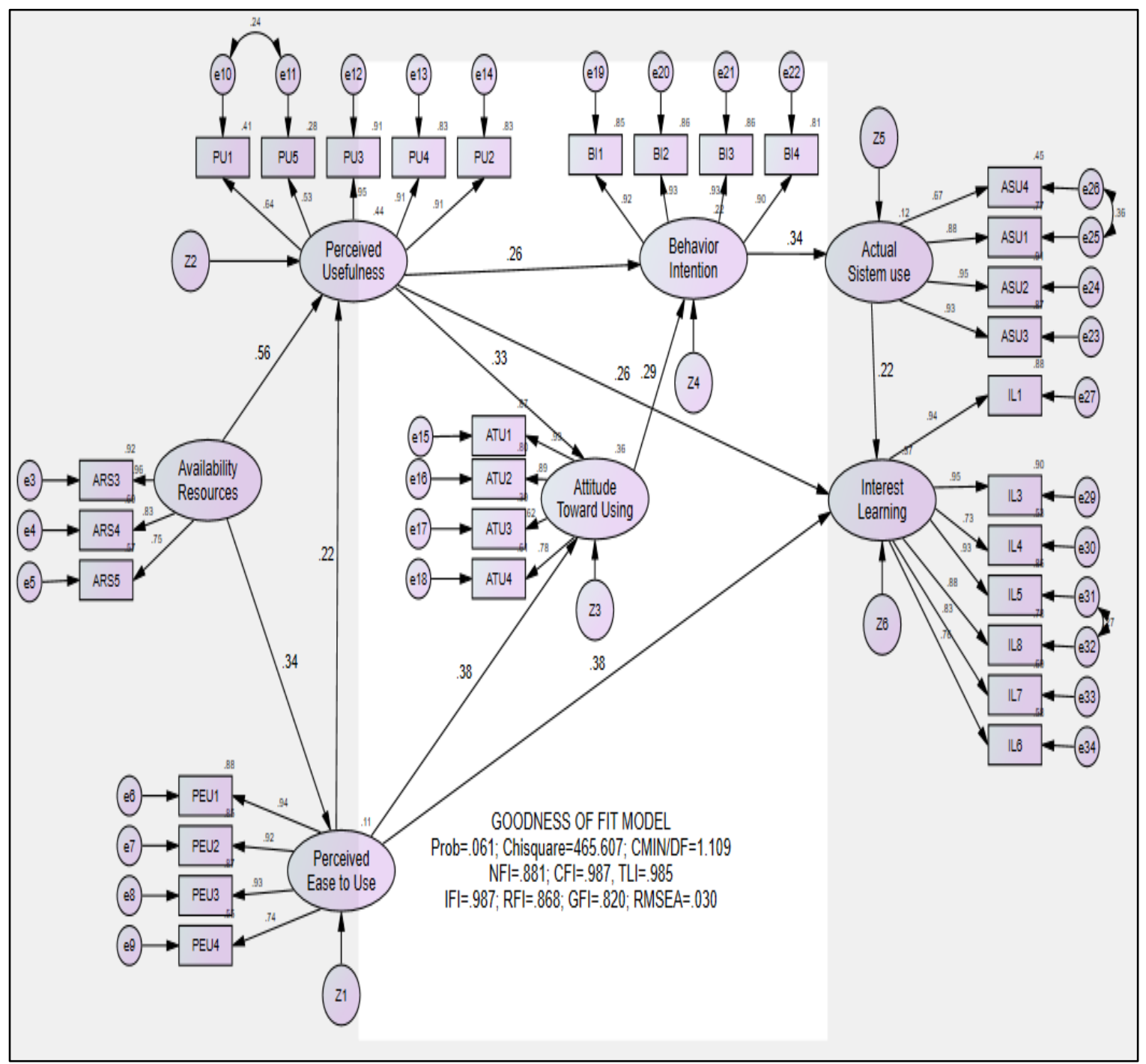


Berdasarkan gambar 4, hasil modifikasi model menunjukkan bahwa model telah memiliki nilai probabilitas > 0,05 dan chi square di bawah chi square yang disyaratkan, hal ini menunjukkan bahwa model telah memiliki matriks kovarian yang sama dengan matriks kovarian populasi, sehingga model telah layak digunakan untuk menguji hipotesis penelitian. Hasil tersebut dapat dilihat pada tabel 6 Goodness Of Fit Indices (GOFI) berikut :

Tabel 6

Hasil Tabel Goodness of Fit Indices (GOFI)

\begin{tabular}{|l|c|c|l|}
\hline \multicolumn{1}{|c|}{ Goodness of Fit Indices } & Keterangan & Cut of value & \multicolumn{1}{|c|}{ Interprestasi } \\
\hline Chi-square (CMin) & 465,067 & $\geq 0,05$ & Kesesuaian Baik \\
\hline Probability (CMin) & 0,061 & $\geq 0,05$ & Kesesuaian Baik \\
\hline $\begin{array}{l}\text { RMSEA (RM error of } \\
\text { approximation) }\end{array}$ & 0,030 & $\leq 0,08$ & Tidak Memenuhi \\
\hline GFI & 0,820 & $\geq 0,90$ & $\begin{array}{l}\text { Kesesuaian } \\
\text { Menengah }\end{array}$ \\
\hline CMIN/df & 1,109 & $\geq 2,00$ & Tidak Memenuhi \\
\hline TLI (Tucker-Lewis Index) & 0,985 & $\geq 0,95$ & Kesesuian Baik \\
\hline CFI (Confirmatory Fit Index) & 0,881 & $\geq 0,95$ & $\begin{array}{l}\text { Kesesuaian } \\
\text { Menengah }\end{array}$ \\
\hline
\end{tabular}

\section{Uji Signifikansi}

Uji signifikansi bertujuan untuk menguji ada tidaknya pengaruh signifikan variabel eksogen terhadap variabel endogen.

Tabel 7

Hasil Uji Signifikansi Regression Weights: (Group number 1 - Default model)

\begin{tabular}{|c|c|c|c|c|c|c|c|}
\hline & & & Estimate & S.E. & C.R. & $\mathrm{P}$ & Label \\
\hline PEU & $<---$ & ARS & .402 & .119 & 3.386 & $* * *$ & par_23 \\
\hline PU & $<---$ & ARS & .530 & .105 & 5.029 & $* * *$ & par_24 \\
\hline PU & $<---$ & PEU & .171 & .068 & 2.530 & .011 & par_27 \\
\hline ATU & $<--$ & PEU & .382 & .098 & 3.897 & $* * *$ & par_25 \\
\hline ATU & $<--$ & PU & .415 & .124 & 3.339 & $* * *$ & par_26 \\
\hline BI & $<--$ & PU & .351 & .139 & 2.523 & .012 & par_28 \\
\hline BI & $<---$ & ATU & .306 & .111 & 2.759 & .006 & par_38 \\
\hline ASU & $<---$ & BI & .255 & .073 & 3.486 & $* * *$ & par_29 \\
\hline IL & $<---$ & PEU & .445 & .109 & 4.080 & $* * *$ & par_32 \\
\hline IL & $<---$ & PU & .388 & .134 & 2.898 & .004 & par_33 \\
\hline IL & $<---$ & ASU & .325 & .123 & 2.650 & .008 & par_34 \\
\hline ARS5 & $<--$ & ARS & 1.000 & & & & \\
\hline
\end{tabular}




\begin{tabular}{|c|c|c|c|c|c|c|c|}
\hline & & & Estimate & S.E. & C.R. & $\mathrm{P}$ & Label \\
\hline ARS4 & $<--$ & ARS & 1.038 & .108 & 9.572 & $* * *$ & par_1 \\
\hline ARS3 & $<--$ & ARS & 1.155 & .115 & 10.023 & $* * *$ & par_2 \\
\hline PU1 & $<--$ & PU & 1.000 & & & & \\
\hline PU5 & $<-$ & PU & .908 & .150 & 6.045 & $* * *$ & par_3 \\
\hline PU3 & $<--$ & PU & 1.479 & .172 & 8.595 & $* * *$ & par_4 \\
\hline PU4 & $<-$ & PU & 1.445 & .174 & 8.310 & $* * *$ & par_5 \\
\hline PEU4 & $<--$ & PEU & 1.000 & & & & \\
\hline PEU3 & $<-$ & PEU & 1.222 & .114 & 10.737 & $* * *$ & par_6 \\
\hline PEU2 & $<--$ & PEU & 1.171 & .111 & 10.546 & $* * *$ & par_7 \\
\hline PEU1 & $<-$ & PEU & 1.154 & .106 & 10.885 & $* * *$ & par_8 \\
\hline PU2 & $<--$ & PU & 1.364 & .165 & 8.267 & $* * *$ & par_9 \\
\hline ATU4 & $<--$ & ATU & 1.000 & & & & \\
\hline ATU3 & $<--$ & ATU & .788 & .112 & 7.049 & $* * *$ & par_10 \\
\hline ATU2 & $<-$ & ATU & 1.038 & .095 & 10.924 & $* * *$ & par_11 \\
\hline ATU1 & $<--$ & ATU & 1.067 & .094 & 11.400 & $* * *$ & par_12 \\
\hline BI1 & $<-$ & BI & 1.000 & & & & \\
\hline $\mathrm{BI} 2$ & $<--$ & $\mathrm{BI}$ & .949 & .053 & 17.921 & $* * *$ & par_13 \\
\hline $\mathrm{BI} 3$ & $<--$ & BI & 1.015 & .058 & 17.638 & $* * *$ & par_14 \\
\hline BI4 & $<--$ & BI & .965 & .059 & 16.340 & $* * *$ & par_15 \\
\hline ASU4 & $<--$ & ASU & 1.000 & & & & \\
\hline ASU1 & $<--$ & ASU & 1.303 & .128 & 10.157 & $* * *$ & par_16 \\
\hline ASU2 & $<--$ & ASU & 1.329 & .147 & 9.059 & $* * *$ & par_17 \\
\hline ASU3 & $<-$ & ASU & 1.298 & .143 & 9.047 & $* * *$ & par_18 \\
\hline IL1 & $<-$ & IL & 1.000 & & & & \\
\hline IL5 & $<-$ & IL & .963 & .049 & 19.530 & $* * *$ & par_19 \\
\hline IL8 & $<--$ & IL & .989 & .061 & 16.303 & $* * *$ & par_20 \\
\hline IL7 & $<-$ & IL & .901 & .065 & 13.885 & $* * *$ & par_21 \\
\hline IL6 & $<--$ & IL & .869 & .076 & 11.501 & $* * *$ & par_22 \\
\hline IL3 & $<-$ & IL & 1.007 & .048 & 21.138 & $* * *$ & par_30 \\
\hline IL4 & $<--$ & IL & .864 & .081 & 10.694 & $* * *$ & par_31 \\
\hline
\end{tabular}

\section{Pengaruh Ketersediaan sumber daya terhadap Kegunaan yang dirasakan}

Nilai $p$ value pengaruh variabel ARS terhadap PU sangat signifikan dengan $\mathrm{cr}$ bertanda positif sebesar 5,029. Oleh karena nilai $p$ value yang diperoleh $<0,05$ dan $\mathrm{cr}$ $>$ 1,96 maka Ho ditolak dan disimpulkan bahwa ketersediaan sumber daya (availability of resources) berpengaruh signifikan terhadap kegunaan yang dirasakan (perceived usefulness). Semakin baik ketersediaan sumber daya yang terdapat dalam $e$ learning maka semakin tinggi persepsi pengguna terhadap manfaat e-learning, begitu sebaliknya.

Hasil penelitian ini sejalan dengan hasil penelitian jurnal Munawar dkk, Berdasakan hasil analisis diketahui besarnya pengaruh variabel Perceived Ease of Use (PEU) terhadap Perceived Usefulness (PU) sejalan dengan pernyataan yang disampaikan Davis bahwa kemudahan pemakaian mempunyai pengaruh terhadap Sistem Informasi (faktor eksternal) sehingga dapat disimpulkan bahwa kemudahan 
penggunaan Sistem Informasi akan menimbulkan perasaan dalam diri seseorang bahwa sistem itu mempunyai kegunaan atau manfaat sehingga menimbulkan rasa nyaman bila bekerja menggunakannya.

\section{Pengaruh Ketersediaan sumber daya terhadap persepsi kemudahan}

Nilai $p$ value pengaruh variabel ARS terhadap PEU sangat signifikan dengan $c r$ bertanda positif sebesar 3,386. Oleh karena nilai $\mathrm{p}$ value yang diperoleh $<0,05 \mathrm{dan} \mathrm{cr}$ $>$ 1,96 maka Ho ditolak dan disimpulkan bahwa ketersediaan sumber daya (availability of resources) berpengaruh signifikan terhadap kemudahan yang dirasakan (perceived ease of use). Semakin baik ketersediaan sumber daya yang terdapat dalam e-learning maka semakin tinggi persepsi pengguna terhadap kemudahan penggunaan e-learning, begitu sebaliknya.

\section{Pengaruh persepsi kemudahan terhadap persepsi kegunaan}

Nilai $p$ value pengaruh variabel PEU terhadap PU sangat signifika $(0,011)$ dengan cr bertanda positif sebesar 2,530. Oleh karena nilai $p$ value yang diperoleh < 0,05 dan $\mathrm{cr}>1,96$ maka Ho ditolak dan disimpulkan bahwa kemudahan yang dirasakan (perceived ease of use) berpengaruh signifikan terhadap kegunaan yang dirasakan (perceived usefulness). Semakin mudah penggunaan e-learning maka semakin tinggi persepsi pengguna terhadap manfaat penggunaan e-learning, begitu sebaliknya. Hasil penelitian ini sejalan dengan hasil penelitian Budi Santoso (2010) yang menunjukkan bahwa persepsi kemudahan sistem perceived ease of use (PEU) berpengaruh positif terhadap persepsi kegunaan perceived usefulness (PU) dalam pemanfaatan STI di Kabupaten Sragen. Hasil penelitian ini juga sejalan dengan hasil penelitian Arief Wibowo (2008) yang menunjukkan bahwa Perceived Ease of Use (PEU) berpengaruh terhadap Perceived Usefulness (PU) Sistem Informasi Dengan Pendekatan Technology Acceptance Model (TAM).

\section{Pengaruh persepsi kegunaan terhadap sikap}

Nilai $p$ value pengaruh variabel PU terhadap ATU sangat signifikan dengan $\mathrm{cr}$ bertanda positif sebesar 3,339. Oleh karena nilai $p$ value yang diperoleh $<0,05$ dan $\mathrm{cr}$ $>$ 1,96 maka Ho ditolak dan disimpulkan bahwa kegunaan yang dirasakan (perceived usefulness) berpengaruh signifikan terhadap sikap terhadap penggunaan (attitude toward using). Semakin baik mudah pengguna menggunakan e-learning maka semakin baik sikap pengguna dalam menggunakan e-learning, begitu sebaliknya. Hasil penelitian ini sejalan dengan hasil penelitian Budi Santoso (2010) yang menunjukkan bahwa persepsi kemudahan sistem perceived usefulness (PU) berpengaruh positif terhadap sikap pengguna dalam pemanfaatan STI di Kabupaten Sragen. Hasil penelitian ini juga sejalan dengan hasil penelitian Arief Wibowo (2008) yang menunjukkan bahwa Perceived usefulness (PU) berpengaruh terhadap sikap pengguna Sistem Informasi Dengan Pendekatan Technology Acceptance Model (TAM). 


\section{Pengaruh persepsi kemudahan terhadap sikap}

Nilai $p$ value pengaruh variabel PEU terhadap ATU sangat signifikan dengan $\mathrm{cr}$ bertanda positif sebesar 2,897. Oleh karena nilai $p$ value yang diperoleh $<0,05$ dan $\mathrm{cr}$ $>$ 1,96 maka Ho ditolak dan disimpulkan bahwa kemudahan yang dirasakan (perceived ease of use) berpengaruh signifikan terhadap sikap terhadap penggunaan (attitude toward using). Semakin mudah pengguna menggunakan e-learning maka semakin baik sikap pengguna dalam menggunakan e-learning, begitu sebaliknya. Hasil penelitian ini sejalan dengan hasil penelitian Budi Santoso (2010) yang menunjukkan bahwa persepsi kemudahan sistem perceived ease of use (PEOU) berpengaruh positif terhadap persepsi kegunaan perceived usefulness (PU) dalam pemanfaatan STI di Kabupaten Sragen. Hasil penelitian ini juga sejalan dengan hasil penelitian Arief Wibowo (2008) yang menunjukkan bahwa perceived ease of use (PEOU) berpengaruh terhadap sikap pengguna Sistem Informasi Dengan Pendekatan Technology Acceptance Model (TAM).

\section{Pengaruh Persepesi Kegunaan terhadap Minat}

Nilai $p$ value pengaruh variabel PU terhadap BI sangat signifikan $(0,012)$ dengan cr bertanda positif sebesar 2,523. Oleh karena nilai $p$ value yang diperoleh < 0,05 dan cr > 1,96 maka Ho ditolak dan disimpulkan bahwa bahwa kegunaan yang dirasakan (perceived usefulness) berpengaruh signifikan terhadap minat penggunaan (behaviour intention). Semakin banyak manfaat penggunaan e-learning maka semakin tinggi minat pengguna menggunakan e-learning, begitu sebaliknya. Hasil penelitian ini sejalan dengan hasil penelitian Arief Wibowo (2008) yang menunjukkan bahwa perceived ease of use (PEOU) berpengaruh terhadap minat penggunaan Sistem Informasi Dengan Pendekatan Technology Acceptance Model (TAM).

\section{Pengaruh Sikap terhadap minat penggunaan}

Nilai $p$ value pengaruh variabel ATU terhadap BI sangat signifikan $(0,006)$ dengan cr bertanda positif sebesar 2,759. Oleh karena nilai $\mathrm{p}$ value yang diperoleh < 0,05 dan $\mathrm{cr}>1,96$ maka Ho ditolak dan disimpulkan bahwa Sikap terhadap penggunaan (attitude toward using) berpengaruh signifikan terhadap minat penggunaan (behaviour intention). Semakin baik sikap pengguna dalam menggunakan e-learning maka semakin tinggi minat pengguna menggunakan $e$ learning, begitu sebaliknya. Siti Tutik Muntianah, Endang Siti Artuti, Devi Farah Azizah (2012) yang menunjukkan bahwa sikap berpenagruh terhadap minat menggunakan tekologi informasi dengan pendekatan technology acceptance model (TAM) dalam Studi Kasus Pada Kegiatan Belajar Mahasiswa Fakultas Ilmu Administrasi Universitas Brawijaya Malang.

\section{Pengaruh minat penggunaan terhadap aktualisasi penggunaan}

Nilai $p$ value pengaruh variabel BI terhadap ASU sangat signifikan $\left({ }^{* * *}\right)$ dengan cr bertanda positif sebesar 3,486. Oleh karena nilai $p$ value yang diperoleh $<0,05$ dan cr $>1,96$ maka Ho ditolak dan disimpulkan bahwa Minat penggunaan (behaviour intention) berpengaruh signifikan terhadap penerimaan sistem (actual system use). 
Semakin baik sikap ptinggi minat pengguna menggunakan e-learning maka semakin diterima keberadaan sistem e-learning, begitu sebaliknya. Hasil penelitian ini juga sejalan dengan hasil penelitian Arief Wibowo (2008) yang menunjukkan bahwa minat menggunakan berpengaruh terhadap aktualisasi penggunaan Sistem Informasi Dengan Pendekatan Technology Acceptance Model (TAM).

\section{Pengaruh persepsi kegunaan terhadap minat belajar}

Nilai $p$ value pengaruh variabel PU terhadap IL sangat signifikan $(0,004)$ dengan cr bertanda positif sebesar 2,898. Oleh karena nilai $p$ value yang diperoleh < 0,05 dan or > 1,96 maka Ho ditolak dan disimpulkan bahwa kegunaan yang dirasakan (perceived usefulness) berpengaruh signifikan terhadap minat belajar (interest of learn). Semakin tinggi kegunaan e-learning maka semakin tinggi minat belajar siswa, begitu sebaliknya. Hasil penelitian ini sejalan dengan hasil penelitian Desy Iba Ricoida, Desi Pibriana pada penelitian di Program Studi Sistem Informasi, STMIK GI MDP pada Mahasiswa, yang menyatakan bahwa sikap penggunaan terhadap minat belajar ada hubungan yang signifikan dan kesimpulannya dapat diterima.

\section{Pengaruh persepsi kemudahan terhadap minat belajar}

Nilai $\mathrm{p}$ value pengaruh variabel PEU terhadap IL sangat signifikan dengan $\mathrm{cr}$ bertanda positif sebesar 4,080. Oleh karena nilai $p$ value yang diperoleh < 0,05 dan $\mathrm{cr}$ $>$ 1,96 maka Ho ditolak dan disimpulkan bahwa bahwa kemudahan yang dirasakan (perceived ease of use) berpengaruh signifikan terhadap minat belajar (interest of learn). Semakin mudah penggunaan e-learning maka semakin tinggi minat belajar siswa, begitu sebaliknya. Hasil penelitian ini sejalan dengan hasil penelitian Desy Iba Ricoida, Desi Pibriana pada penelitian di Program Studi Sistem Informasi, STMIK GI MDP pada Mahasiswa, yang menyatakan bahwa persepsi kemudahan terhadap minat belajar ada hubungan yang signifikan dan kesimpulannya dapat diterima.

\section{Pengaruh aktualisasi penggunaan terhadap minat belajar}

Nilai $p$ value pengaruh variabel ASU terhadap IL sangat signifikan $(0,008)$ dengan cr bertanda positif sebesar 2,650. Oleh karena nilai $\mathrm{p}$ value yang diperoleh < 0,05 dan cr $>1,96$ maka Ho ditolak dan disimpulkan bahwa penerimaan sistem (actual system use) berpengaruh signifikan terhadap minat belajar (interest of learn). Semakin aktual penggunaan e-learning maka semakin tinggi minat belajar siswa, begitu sebaliknya. Hasil penelitian ini sejalan dengan hasil penelitian Nurmaili Dalimunthe dan Himawan Wibisono yang melakukan penelitian pada SMK Labor pekan Baru actual sistem use mempengaruhi minat belajar dalam penggunaan sistem e-learning, dan hal ini sesuai dengan hasil penelitian ini .

\section{KESIMPULAN}

Kesimpulan yang diperoleh dari hasil penelitian ini adalah sebagai berikut : Pertama, ketersediaan sumber daya (availability of resources) berpengaruh signifikan terhadap kegunaan yang dirasakan (perceived usefulness). Semakin baik ketersediaan sumber 
daya yang terdapat dalam e-learning maka semakin tinggi persepsi pengguna terhadap manfaat e-learning, begitu sebaliknya.

Kedua, ketersediaan sumber daya (availability of resources) berpengaruh signifikan terhadap kemudahan yang dirasakan (perceived ease of use). Semakin baik ketersediaan sumber daya yang terdapat dalam e-learning maka semakin tinggi persepsi pengguna terhadap kemudahan penggunaan e-learning, begitu sebaliknya.

Ketiga, kemudahan yang dirasakan (perceived ease of use) berpengaruh signifikan terhadap kegunaan yang dirasakan (perceived usefulness). Semakin mudah penggunaan e-learning maka semakin tinggi persepsi pengguna terhadap manfaat penggunaan e-learning, begitu sebaliknya.

Keempat, kegunaan yang dirasakan (perceived usefulness) berpengaruh signifikan terhadap sikap penggunaan (attitude toward using). Semakin baik sikap pengguna menggunakan e-learning maka semakin baik sikap pengguna dalam menggunakan $e$ learning, begitu sebaliknya.

Kelima, kemudahan yang dirasakan (perceived ease of use) berpengaruh signifikan terhadap sikap penggunaan (attitude toward using). Semakin mudah pengguna menggunakan e-learning maka semakin baik sikap pengguna dalam menggunakan e-learning, begitu sebaliknya.

Keenam, kegunaan yang dirasakan (perceived usefulness) berpengaruh signifikan terhadap minat penggunaan (behaviour intention). Semakin banyak manfaat penggunaan e-learning maka semakin tinggi minat pengguna menggunakan $e$ learning, begitu sebaliknya.

Ketujuh, Sikap terhadap penggunaan (attitude toward using) berpengaruh signifikan terhadap minat penggunaan (behaviour intention). Semakin baik sikap pengguna dalam menggunakan e-learning maka semakin tinggi minat pengguna menggunakan e-learning, begitu sebaliknya.

Kedelapan, minat penggunaan (behaviour intention) berpengaruh signifikan terhadap penerimaan sistem (actual system use). Semakin baik sikap minat pengguna menggunakan e-learning maka semakin diterima keberadaan sistem e-learning, begitu sebaliknya.

Kesembilan, Kegunaan yang dirasakan (perceived usefulness) berpengaruh signifikan terhadap minat belajar (interest of learnn). Semakin tinggi kegunaan $e-$ learning maka semakin tinggi minat belajar siswa, begitu sebaliknya.

Kesepuluh, kemudahan yang dirasakan (perceived ease of use) berpengaruh signifikan terhadap minat belajar (interest of learn). Semakin mudah penggunaan $e-$ learning maka semakin tinggi minat belajar siswa, begitu sebaliknya.

Kesebelas, Penerimaan sistem (actual system use) berpengaruh signifikan terhadap minat belajar (interest of learn). Semakin aktual penggunaan e-learning maka semakin tinggi minat belajar siswa, begitu sebaliknya. 


\section{Referensi}

Akhmad Faturrohman. (2011). Pengaruh Pengembangan Model Pembelajaran E-Learning terhadap Prestasi Belajar Mahasiswa Program Pasca Sarjana Magister Teknik Informatika. Jurnal Tesis. Universitas Dian Nuswantoro Semarang.

Chin. W. W., T. P. (1995). On The use Usefulness, ease of use of structural equation modeling iChin. W. W., T. P. (1995). On The use Usefulness, ease of use of structural equation modeling in MIS Research: A note of caution. MIS Quarterly, 23(1), 63-70.n MIS Research: A note of cau. MIS Quarterly, 23(1), 63-70.

D, D. F. (1989). Perceived Usefulness, Perceived Ease of Use and Acceptance of Information Technology, MIS Quarterly, 13(3), 319.

Desy Iba Ricoida, D. P. (2017). Pengaruh Penggunaan Internet Terhadap Minat Dan Perilaku Belajar Mahasiswa, ,. Jurnal Seminar Nasional Sistem Informasi Indonesia Program Studi Sistem Informasi, STMIK GI MDP, 3(2), 2017.

Eddy, E.R. and Tannenbaum, S. . (2003). Transfer in an e - learning context. In Improving Learning Transfer in Organizations (in Holton, p. 2003). Jossey-Bass, San Francisco, CA.

Herlina. (2010). Minat Belajar. Jakarta: Bumi Aksara.

Johnson, R.D., Hornik, S.R. and Salas, E. (2008). An empirical examination of factors contributing to the creation of successful e- learning environments. International Journal of Human-Computer Studies, 66, 356-369.

Jose Luis Arquero, Carmen Fernández-Polvillo,Trevor Hassall and John Joyce, . (2015). Vocation, motivation and approaches to learning: a comparative study. Education + Training, 57(1), 13-30. https://doi.org/10.1108/ET-02-2013-0014

Khafid, M. (2004). FAKTOR - FAKTOR YANG MEMPENGARUHI KETUNTASAN BELAJAR AKUNTANSI : MOTIVASI BELAJAR SEBAGAI VARIABEL INTERVENING, 1.

Rauniar, R., Rawski, G., Yang, J., \& Johnson, B. (2013). Technology acceptance model ( TAM ) and social media usage : an empirical study on Facebook. Journal of Enterprise Information Management, Vol. 27(1), 5. https:/ / doi.org/10.1108/JEIM04-2012-0011

Sheldon, K. M., Turban, D. B., Brown, K. G., Barrick, M. R., \& Judge, T. A. (2012). Motivation to learn and learning strategies IT courses in a library and information. Journal Personnel and Human Education, 61(1), 41-56. https:/ / doi.org/10.1108/00242531211207415

Sitzmann, T., Kraiger, K., Stewart, D. and Wisher, R. (2006). The comparative effectiveness of web-based and classroom instruction: a meta- analysis. Personnel Psychology, 59, 623-664.

Slameto. (2015). Belajar dan Faktor-Faktor yang Mempengaruhinya (cetakan ke). Jakarta: Rineka Cipta.

Subakdo Eko Yulianto. (2011). Pengaruh Persepsi Kemudahan Dan Persepsi 
Kemanfaatan Terhadap Pemanfaatan E-Learning Dengan Model TAM Di SMK Muhammadiyah 3 Yogyakarta. JBTI, II(1).

Syaiful Bahri Djamarah. (2014). Prestasi Belajar dan Kompetensi Guru. Surabaya: USAHA NASIONAL.

Ulrich Schiefele. (1991). Interest, Learning, and Motivation. Educational Psychologist.

Welsh, E.T., Wanberg, C.R., Brown, K.G. and Simmering, M. . (2003). E -learning: emerging uses, empirical results and future directions. International Journal of Training and Development, 7, 245-258.

Widiyanto, A., Hikmawan, M. D., \& Riswanda, riswanda. (2019). JSPG: Journal of Social Politics and Governance Implementasi Rencana Aksi Nasional Bela Negara Berdasarkan Instruksi Presiden Nomor 7 Tahun 2018 Oleh Dewan Ketahanan Nasional Republik Indonesia. Journal of Social Politics and Governance, 1(2), 95-115.

Yousafzai, S. Y., Foxall, G. R., \& Pallister, J. G. (2007). Technology acceptance : a meta-analysis of the TAM : Part 1. Journal of Modelling in Management, Vol. 2(3), 251-280. https://doi.org/10.1108/17465660710834453 